\title{
Pharmacogenomics of Alcohol Addiction: Personalizing Pharmacologic Treatment of Alcohol Dependence
}

\author{
Georgia Ragia ${ }^{1,2}$, Vangelis G. Manolopoulos ${ }^{1,3}$ \\ ${ }^{1}$ Laboratory of Pharmacology, Medical School, Democritus University of Thrace, \\ Alexandroupolis, Greece \\ 2 DNALEX S.A., Leontaridou 2, Alexandroupolis, Greece \\ ${ }^{3}$ Clinical Pharmacology Unit, Academic General Hospital of Evros, Alexandroupolis, Greece
}

\section{SUMMARY}

Alcohol dependence is a serious psychiatric disorder with harmful physical, mental and social consequences, and a high probability of a chronic relapsing course. The field of pharmacologic treatment of alcohol dependence and craving is expanding rapidly; the drugs that have been found to reduce relapse rates or drinking in alcohol-dependent patients and are approved for treatment of alcohol dependence are naltrexone, acamprosate and disulfiram, whereas also topiramate appears as a promising therapy. For many patients, however, these treatments are not effective. Evidence from a number of different studies suggests that genetic variation is a significant contributor to interindividual variation of clinical presentation of alcohol problems and response to a given treatment. The aim of the present review is to summarize and discuss the findings on the association between gene polymorphisms and the response to alcohol dependence treatment medications. It is anticipated that future implementation of pharmacogenomics in clinical practice will help personalize alcohol dependence drug treatment, and development personalized hospital pharmacology.

Keywords: Alcohol, addiction, naltrexone, topiramate, disulfiram, acamprosate, pharmacogenetics, personalized drug treatment, hospital pharmacology

\section{INTRODUCTION}

Alcohol dependence is a serious psychiatric disorder with harmful physical, mental and social consequences, and a high probability of a chronic relapsing course. According to the 2014 global status report on alcohol and health by the World Health Organization, in 2012, about 3.3 million deaths, or $5.9 \%$ of all global deaths, and $5.1 \%$ of the global burden of disease and injury, were attributable to alcohol consumption [1]. Globally, Europe is the region with the highest consumption of alcohol per capita [1]. Alcohol dependence is associated with psychiatric conditions such as major depression, dysthymia, mania, hypomania, panic disorder, phobias, generalized anxiety disorder, personality disorders, any drug 
use disorder, schizophrenia, and suicide [2]. On the other hand, psychiatric comorbidity is associated with alcohol-related symptoms of greater severity [2]. Long-term relapse prevention in alcohol-dependent patients is based on psychotherapy and pharmacotherapy. Although psychotherapy is in some cases effective in reducing alcohol consumption and in maintaining abstinence, without a pharmacological adjunct to psychosocial therapy, the clinical outcome is poor, with up to $70 \%$ of patients resuming drinking within 1 year [3-5].

The field of pharmacologic treatment of alcohol dependence and craving is expanding rapidly [6]. To date, the drugs that have been found to reduce relapse rates or drinking in alcohol-dependent patients and are approved for treatment of alcohol dependence are naltrexone, acamprosate and disulfiram, whereas also topiramate appears as a promising therapy [7]. For many patients, however, these treatments are not effective. Evidence from a number of different studies suggests that genetic variation is a significant contributor to interindividual variation of clinical presentation of alcohol problems and response to a given treatment.

Pharmacogenomics is the area of medicine that studies the genetic factors that influence drug response and toxicity $[8,9]$. In this context, pharmacogenomics paves the path to personalized medicine. The rapidly advancing field of pharmacogenomics is a promising area of investigation, focusing on genetic variations in components that affect drug pharmacokinetics and pharmacodynamics [10-17] or that are involved in their therapeutic mechanisms and/or cause of their adverse events $[18,19]$. Application of pharmacogenomics explains some of the interindividual variable response to various classes of drugs, such as psychiatric drugs [20,21], antidiabetics [22] and oral coumarinic anticoagulants [23]. Efforts are now focusing on the development of genotype-based guidelines that will help clinicians in incorporating pharmacogenomic knowledge in their routine clinical practice. Among the most solid and recent pharmacogenomic applications is the genotype-guided dosing algorithm of oral coumarinic anticoagulants; results of two large randomised clinical trials conducted in European populations showed that patients who received genotypeguided dosing of the oral coumarinic anticoagulants acenocoumarol, phenprocoumon and warfarin had increased percentage of time in the therapeutic range compared to controls $[24,25]$.

In view of these developments in several pharmacotherapeutic areas it was inevitable that also the field of personalization of alcohol dependence treatment would get a boost from pharmacogenomics. The choice of alcohol-dependence treatment may improve by identifying genetic variations that predict individual responses to therapeutic interventions. Data has accumulated suggesting that specific genetic polymorphisms govern the therapeutic response, the dose requirements and the risk of experiencing adverse effects to the respective therapy [26]. Therefore, pharmacogenomics of alcohol dependence treatment is an emerging field with promising application in psychiatry. Below we discuss evidence for genetic variation in the effect of the 4 anti-craving drugs.

Information of all gene polymorphisms that have been studied in association with drug response - their chromosome location, effect on encoded protein, and the medication they affect - is presented in Table 1. To further help the reader in easily assessing the published studies, all currently available data on gene polymorphisms associated with alcohol dependence drug response are briefly listed in three tables: Table 2 presents gene polymorphisms studied in association with the opioid antagonists naltrexone, nalmofene and naloxone response, Table 4 presents gene polymorphisms studied in association with acamprosate response, Table 5 presents gene polymorphisms studied in association with disulfiram response and Table 6 presents gene polymorphisms studied in association with topiramate response. Furthermore, given the significance of clinical trials assessing implementation of pharmacogenomics in routine clinical practice, completed and ongoing clinical trials on alcohol addiction pharmacogenomics are listed in Table 3.

\section{PHARMACOGENOMICS OF MEDICATIONS USED TO TREAT ALCOHOL DEPENDENCE}

\section{Opioid antagonists: Naltrexone, nalmofene and naloxone}

Naltrexone is a specific opioid antagonist targeting endogenous opioid receptors, particularly $\mu$-receptors. Blocking opioid receptors with naltrexone leads to less alcohol-induced 


\begin{tabular}{|c|c|c|c|c|c|c|c|}
\hline $\begin{array}{c}\text { Gene } \\
\text { (protein) }\end{array}$ & $\begin{array}{l}\text { Genomic } \\
\text { locus }\end{array}$ & SNP ID* & $\begin{array}{l}\text { SNP gene } \\
\text { location }\end{array}$ & $\begin{array}{l}\text { Amino acid } \\
\text { substitu- } \\
\text { tion }\end{array}$ & $\begin{array}{l}\text { Effect on } \\
\text { encoded } \\
\text { product }\end{array}$ & $M A F^{*}$ & $\begin{array}{l}\text { Drug } \\
\text { studied in } \\
\text { association } \\
\text { with }\end{array}$ \\
\hline OPRMI & $6 q 25.2$ & $\begin{array}{l}\text { rs1799971A>G } \\
\text { (c.A118G) }\end{array}$ & $\begin{array}{l}\text { Exon 1, } \\
\text { missense, } \\
\text { non syn- } \\
\text { onymous } \\
\text { amino } \\
\text { acid sub- } \\
\text { stitution }\end{array}$ & Asn40Asp & $\begin{array}{l}\text { Increased } \\
\text { binding of } \\
\text { B-endorphin }\end{array}$ & 0.19 & Naltrexone \\
\hline OPRK1 & $8 q 11.2$ & $\begin{array}{l}\text { rs997917T>C } \\
(c .258-4707 A>G, \\
\text { g. } 7312553 T>C)\end{array}$ & Intron 1 & - & Unknown & 0.429 & Naltrexone \\
\hline OPRD1 & $\begin{array}{l}\text { 1p36.1- } \\
\text { p34.3 }\end{array}$ & $\begin{array}{l}\text { rs4654327A>G } \\
\left(c .{ }^{*} 343 G>A,\right. \\
\text { g. } 28277638 G>A)\end{array}$ & 3' UTR & - & $\begin{array}{l}\text { Potential } \\
\text { effect on } \\
\text { transcrip- } \\
\text { tion levels } \\
\end{array}$ & 0.431 & Naltrexone \\
\hline $\begin{array}{l}\text { SLC6A3 } \\
\text { (DAT) }\end{array}$ & $5 p 15.3$ & $\begin{array}{l}\text { rs28363170 } \\
\text { (c. }{ }^{*} 987 \text { *988ins } \\
\text { ACT GGA GCG } \\
\text { TGT ACT ACC CCA } \\
\text { GGA CGC ATG } \\
\text { CAG GGC CCC C) } \\
3 \text { to } 11 \text { repeats, } \\
\text { most common } \\
\text { alleles are } 9 \text { and } \\
10 \text { repeats }\end{array}$ & 3' UTR & - & $\begin{array}{l}\text { Regulation } \\
\text { of DAT gene } \\
\text { expression } \\
\text { potential } \\
\text { effect on } \\
\text { transcrip- } \\
\text { tion levels }\end{array}$ & NA & Naltrexone \\
\hline GABRA6 & $5 q 34$ & $\begin{array}{l}\text { rs3219151T>C } \\
\text { (c. }{ }^{*} 135 C>T, g . \\
5940584 C>T)\end{array}$ & 3' UTR & - & $\begin{array}{l}\text { Potential } \\
\text { effect on } \\
\text { transcrip- } \\
\text { tion levels }\end{array}$ & 0.544 & $\begin{array}{l}\text { Acampro- } \\
\text { sate }\end{array}$ \\
\hline GABRB2 & $5 q 34$ & $\begin{array}{l}r s 2229944 C>T \\
(c .1194 C>T, \\
\text { g.5532988G >A) }\end{array}$ & $\begin{array}{l}\text { Exon 10, } \\
\text { syn- } \\
\text { onymous } \\
\text { amino } \\
\text { acid sub- } \\
\text { stitution }\end{array}$ & Ala436= & Unknown & 0.109 & $\begin{array}{l}\text { Acampro- } \\
\text { sate }\end{array}$ \\
\hline $\begin{array}{l}\text { DRD2 } \\
\text { (actual } \\
\text { ANKK1) }\end{array}$ & 11q23.2 & $\begin{array}{l}\text { rs1800497 C>T } \\
\text { (c.2137G>A, } \\
\text { g. } 25397210 G>A)\end{array}$ & $\begin{array}{l}\text { Exon } 8 \text {, } \\
\text { missense, } \\
\text { non syn- } \\
\text { onymous } \\
\text { amino } \\
\text { acid sub- } \\
\text { stitution }\end{array}$ & Glu713Lys & $\begin{array}{l}\text { Reduced } \\
\text { number of } \\
\text { DRD2 mol- } \\
\text { ecules and } \\
\text { receptor } \\
\text { binding }\end{array}$ & 0.296 & $\begin{array}{l}\text { Acampro- } \\
\text { sate }\end{array}$ \\
\hline DBH & $9 q 34.2$ & $\begin{array}{l}r s 1611115 C>T \\
\text { (c. }-979 T>C, g . \\
\text { C1021T) }\end{array}$ & $\begin{array}{l}\text { Promoter, } \\
\text { effect on } \\
\text { transcrip- } \\
\text { tion level }\end{array}$ & - & $\begin{array}{l}\text { Reduced } \\
\text { transcrip- } \\
\text { tion }\end{array}$ & 0.208 & Disulfiram \\
\hline GRIK1 & $21 q 22.11$ & $\begin{array}{l}r s 2832407 A>C \\
(c .1251+1338 A>C)\end{array}$ & $\begin{array}{l}\text { Intron 9, } \\
\text { unknown }\end{array}$ & - & Unknown & 0.448 & Topiramate \\
\hline
\end{tabular}

pleasure and, ultimately, less craving and relapse. $\mu$-opioid receptors primarily bind $\beta$-endorphin and diffuse this binding via Gprotein signaling that alters neuronal firing and leads to neuroadaptive changes [27]. Other opioid receptor antagonists with similar to naltrexone properties are naloxone and nalefene, however, naltrexone is more commonly prescribed in alcohol addiction therapy. A
Table 1. Summary of the genetic locus and gene polymorphisms that have been examined in association with response to alcohol dependence medications

MAF: Minor Allele Frequency * as reported in dbSNP Short Genetic Variations database (www.ncbi.nlm.nih.gov/projects/SNP/snp_ref.cgi?rs) 
Since naltrexone targets the $\mu$-opioid receptor, OPRM1 $118 A>G$ gene polymorphism is an attractive candidate to assess the interindividual differential response to naltrexone [27]. Indeed, results of several studies suggest that $118 \mathrm{G}$ carriers respond better to naltrexone treatment. For consistency, throughout the manuscript we refer to $O P R M 1$ polymorphism with nucleotide substitution nomenclature.

Several studies have assessed the potential effect of OPRM1A118G polymorphism on altered endogenous response associated with response to alcohol pharmacotherapy (Table 2). Wand and colleagues have tested the hypothesis that OPRM1 A118G polymorphism influences the hypothalamic-pituitary-adrenal (HPA) axis activation induced by opioid receptor blockage; opioid receptor antagonists such as naloxone, nalmefene and naltrexone affect disinhibition of HPA axis leading to cortisol and adrenocorticotropin hormones release [29]. A total of 39 healthy men receiving five doses of naloxone were included in the study. The authors have found that carriers of $118 G$ allele had greater cortisol response to receptor blockage and different increase (between 30-90 minutes) and decrease (after 90 minutes) rate of adrenocorticotropin [29]. Similar results were obtained by Hernandez-Avila and colleagues who also estimated cortisol and adrenocorticotropin response to intravenous naloxone or placebo [30]. In a total of 30 healthy participants, carriage of $118 \mathrm{G}$ allele was associated with higher cortisol concentration both at baseline and after naloxone infusion, with greater peak cortisol response and greater area under the cortisol time curve [30]. The increased cortisol response to naloxone in $118 \mathrm{G}$ carriers was also replicated in the study of Chong and colleagues in a total of 74 participants who received five doses of naloxone [31]. In the latter studies, no effect on plasma adrenocorticotropin was noticed. In a different study, Ray and colleagues found an association of OPRM1 $118 \mathrm{G}$ allele with increase of allopregnanolole levels in 32 naltrexone treated heavy drinkers; allopregnanolole is a GABAergic neuroactive steroid that has been associated with naltrexone pharmacotherapy [32]. Naltrexone increased allopregnanolole in OPRM1 $118 \mathrm{G}$ cariers but not in 118AA homozygotes, whereas no effect on cortisol levels was present. Based on these results the authors proposed that the enhanced therapeutic response of $118 \mathrm{G}$ carriers to naltrexone could be attributed in part to the ability of the drug to increase allopregnanolole levels at least in these individuals [32]. These results suggest that OPRM1 A118G polymorphism is associated with differential response to physiological processes that are mainly regulated via activation of opioid receptors.

A different approach was followed by Ray and colleagues who have tested the hypothesis that individuals who have a genetic predisposition to greater feelings of euphoria after consuming alcohol due to OPRM1 A118G polymorphism also present with more successful response to the medication that reduces feelings euphoria [33]. In 38 students with a moderate or heavier drinking pattern who intravenously received alcohol, feelings of euphoria were recorded. Carriers of $118 \mathrm{G}$ allele reported greater feelings of intoxication, higher increases in alcohol-induced stimulation and higher increases in state happiness compared to 118AA homozygotes [33]. Results were replicated by the same research team in 40 participants who underwent the same alcohol challenge [34].Similarly to their previous report, carriers of $118 \mathrm{G}$ allele reported higher alcohol-induced euphoria compared to $118 \mathrm{AA}$ homozygotes [34].

Studies that assess the potential association of OPRM1 A118G polymorphism with naltrexone response, analyze several drinking outcomes such as craving, relapse and abstinence, and recruit participants who are alcohol-dependent, treatment- or non-treatment seeking. First in vivo evidence on association of OPRM1 A118G polymorphism with naltrexone response was published in 2003. Oslin and colleagues have analyzed the association between OPRM1 A118G genotype and drinking outcomesin 71 alcohol-dependent individuals of European descent [35]. Additionally to naltrexone treated individuals (treated with naltrexone 50 or $100 \mathrm{mg}$ for 12 weeks), a placebo treated group of 59 individuals was also included in the study. The authors have shown that, compared to $118 \mathrm{AA}$ individuals, carriers of $118 \mathrm{G}$ allele had a greater chance not to return to heavy drinking $(\mathrm{OR}=3.52)$ and also had significantly longer time to first relapse $(\mathrm{OR}=2.79)$ [35]. Ray and colleagues have tested the hypothesis that OPRM1 A118G polymorphism acts as modulator of naltrexone effects on alcohol sensitivity and have found that naltrexone reduced self-reported alcohol-induced euphoria in participants with at least one $118 \mathrm{G}$ 
allele [34]. Similarly, in the pharmacogenetic arm of the clinical trial NCT00006206, the researchers examined the role of OPRM1 A118G polymorphism as a predictor of naltrexone treatment response [36]. Among individuals initially recruited, 300 were randomized on naltrexone therapy. Alcohol dependent patients who were treated with naltrexone and had at least one $118 \mathrm{G}$ allele showed an increasing trend in abstinent days over time and fewer heavy drinking days over time, while additionally they also had the best outcome [36].

During the last five years, there has been an increase in publications on the association of OPRM1 A118G polymorphism with naltrexone response, and the majority of the studies support the hypothesis that carriers of $118 \mathrm{G}$ allele have enhanced response to naltrexone. In 2009, Ooteman and colleagues have tested the hypothesis that naltrexone primarily exerts its effects in patients characterized by genetic variation in opioidergic system whereas acamprosate primarily exerts its effects in patients characterized by variations in glutamatergic system [37]. A total of 52 naltrexone treated and 56 acamprosate treated alcohol dependent patientswere included in genetic analyses. The authors have found that naltrexone outperformed acamprosate in OPRM1 $118 \mathrm{G}$ allele carriers, whereas acamprosate outperformed naltrexone in the OPRM1 118AA group [37]. These results support a role of OPRM1 A118G genotyping prior of therapy choice. Results on the association of genetic factors with acamprosate response are discussed in detail in Acamprosate section that follows. Oroszi and colleagues have also found an association of $118 \mathrm{G}$ allele and good clinical response to naltrexone [38]. In 146 alcohol dependent patients the authors have used a haplotype-based procedure and have showed that higher percentage of naltrexone-treated patients carrying the haplotype consisted by $118 \mathrm{G}$ allele had good clinical outcome compared to non-carriers [38]. It should be noted that the sole haplotype that was associated with naltrexone response was the one carrying the $118 \mathrm{G}$ allele. In a different prospective study in 63 alcohol-dependent Korean patients treated with naltrexone $25 \mathrm{mg} /$ day for first 3 days and $50 \mathrm{mg} /$ day for the remaining days ofa 12 -week treatment, Kim and colleagues have found that patients with at least one $118 \mathrm{G}$ allele took significantly longer time to relapse than $118 \mathrm{AA}$ homozygotes [39]. These results highlight that the association of OPRM1 A118G polymorphism with naltrexone responseoutscales potential ethnic differences. In a following study in 40 social drinkers administered naltrexone $25 \mathrm{mg}$ for first day and $50 \mathrm{mg}$ for the rest 5 days of the 6-days follow-up, Setiawan and colleagues analyzed the association of OPRM1 A118G polymorphism with subjective effects of alcohol [40]. Carriers of $118 \mathrm{G}$ allele reported experiencing decreased euphoria during naltrexone treatment after seeing and drinking alcohol [40]. Results of a double-blinded, randomized, placebo-controlled laboratory trial on naltrexone that included 35 non-treatment seeking Asian Americans heavy drinkers have also showed that $118 \mathrm{G}$ carriers experience greater alcohol-induced sedation and subjective intoxication, and lower alcohol craving compared to 118AA [41]. OPRM1 118G allele was also associated with increased percentage of non-hazardous drinking in a study that included 112 European problem drinkers treated with naltrexone $100 \mathrm{mg} /$ day for 12 weeks [42].

Urge to drink has also been analyzed as an outcome of naltrexone response. McGeary and colleagues have analyzed the association of OPRM1 A118G polymoprhism with the urge to drink alcohol in a total of 90 individuals consisting a mixed of population of non treatment seeking alcohol dependent individuals and non alcohol dependent individuals; 42 of them were treated with naltrexone $50 \mathrm{mg} /$ day for 3 weeks [43]. The authors have found that OPRM1 $118 \mathrm{G}$ carriers showed greater urge to drink when receiving naltrexone compared with placebo. Urge to drink alcohol may become more salient when one is attempting to avoid drinking and may be a marker for the effort required to abstain from drinking. Since this urge may be more predictive of drinking among treatment seekers, the authors mention that their results cannot be generalized to alcohol dependent individuals in treatment [43]. Similar results were presented by Kranzler and colleages, who analyzed the association of OPRM1 A118G polymorphism with desire to drink in 81 problem drinkers who received naltrexone $50 \mathrm{mg} /$ day [44]. In this study, registered as NCT00369408 in ClinicalTrials.gov, carriers of $118 \mathrm{G}$ allele showed a stronger evening drinking desire and were at greater risk of drinking more than 118AA homozygotes, which was attenuated by naltrexone [44].

It is widely recognized that, in all fields of medicine, pharmacogenomic applica- 
tion has the greater possible impact on clinical practice when multiple gene analyses are carried out and that once a gene has been documented to be clearly associated with a drug response, then studies of other genes should include the previous genes in analyses [16, 45]. This approach has been applied by Ashenhurst and colleagues; in 40 heavy drinkers who underwent an intravenous alcohol challenge paradigm after receiving 50mg of naltrexone, the researchers analyzed the pharmacogenetic effect of delta and kappa opioid receptor gene polymorphisms on subjective responses to alcohol after controlling for OPRM1 A118G polymorphism [46]. The authors have found that OPRK1 rs997917 and OPRD1 rs4654327 gene polymorphisms were associated with response to alcohol and this effect remained significant after controlling for OPRM1 A118G polymorphism [46]. Anton and colleagues have analyzed both OPRM1 A118G and dopamine transporter (DAT) 9 and 10 VNTRs in 83 nontreatment seeking alcohol dependent individuals receiving either placebo or naltrexone $25 \mathrm{mg}$ for 2 days and $50 \mathrm{mg}$ for 5 days for a week [47]. The authors did not find a role of OPRM1 A118G polymorphism alone with response to naltrexone, but they report an epistasis between $O P R M 1$ and $D A T$ genes. In non-carriers of $118 G$ allele, carriers of $D A T$ 9 VNTR had more stimulation to alcohol or medication treatment and in these individuals naltrexone reduced the number of drinks consumed per day [47]. Schacht and colleagues have also reported a similar interaction of OPRM1 and DAT genes [48]. In the study, a total of 74 non treatment seeking alcohol dependent individuals treated with naltrexone $50 \mathrm{mg}$ or placebo for 1 week were included. Results of fMRI alcohol cue reactivity task performed on day 6 showed that OPRM1 A118G polymorphism did not have a main effect on medication, however, $118 \mathrm{G}$ carriers who also carried DAT 10VNTR had less stimulation than 9 VNTR carriers [48]. More recently, in a cohort of 43 alcohol dependent individuals, the interaction of OPRM1 with DAT was replicated [49]. OPRM1 $118 \mathrm{G}$ carriers and DAT 10 VNTR homozygotes reported steeper increase in stimulation and positive mood across rising alcohol concentration [49]. The consistency in OPRM1-DAT interaction results suggests that opioidergic and dopaminergic systems interact and determine the reinforcing properties of alcohol.
The need to draw firm conclusions on the association of gene polymorphisms with response to a given pharmacotherapy has led to a type of studies called meta-analysis; a statistical procedure that integrates the results of several independent studies that were conducted analyzing the same outcome [50]. Currently, only one meta-analysis on the effect of OPRM1 A118G polymorphism on naltrexone response has been published [51]. Meta-analysis included a total of 6 studies that assessed the pharmacogenetic effect of OPRM1 A118G polymorphism on naltrexone response in alcohol-dependent patients. Overall the results support the evidence that naltrexone treated patients carrying $118 G$ allele have lower relapse rates than those who are 118AA homozygous $(\mathrm{OR}=1.97)$, but similar abstinence rates [51].

The abovementioned results on the association of OPRM1 A118G polymorphism with naltrexone response were not replicated in all studies. Gelernter and colleagues have assessed the association of OPRM1 A118G polymorphism with naltrexone response in 215 alcohol-dependent male subjects treated with naltrexone $50 \mathrm{mg} /$ day for 3 to 12 months [52]. The authors did not find an association of OPRM1 polymorphisms with rate of and time to relapse [52]. Similarly, Mitchell and colleagues did not find a contribution of OPRM1 gene polymorphism on naltrexone effect estimated by self reported ethanol consumption [53]. This study included a total of 25 subjects treated with naltrexone $50 \mathrm{mg} /$ day [53]. O'Malley and colleagues have also analyzed the association of OPRM1 A118G polymorphism with naltrexone response in 101 alcohol-dependent Alaskians treated for 16 weeks with placebo, naltrexone $50 \mathrm{mg}$ monotherapy or naltrexone $50 \mathrm{mg}$ and sertraline $100 \mathrm{mg}$ combined therapy [54]. OPRM1 genotyping was successful for 92 participants, however, all further analyses were restricted in 75 participants who were 118AA homozygous, of whom 52 were treated with naltrexone as monotherapy or combined therapy. When the effect of treatments were compared within this subgroup, the pattern of OPRM1 polymorphism association was similar to the results in the total sample, suggesting that OPRM1 polymorphism is not associated with enhanced response to naltrexone [54]. In 2008, Tidey and colleagues analyzed the association of OPRM1 A118G polymorphism with drink data, urge levels and subjective effects on alcohol consumption in 
180 heavy drinkers, $63 \%$ of whom were alcohol-dependent [55]. 88 individuals received naltrexone $50 \mathrm{mg} /$ day for 3 weeks. Naltrexone significantly decreased percent drinking days, however, OPRM1 A118G polymorphism was not a moderator of naltrexone response [55]. Similarly, Coller and colleagues examined prospectively in 100 alcohol dependent patients treated with naltrexone $50 \mathrm{mg}$ for 12 weeks the association of OPRM1 A118G polymorphism with several clinical outcomes of naltrexone treatment, such as time to first relapse and craving [56]. The authors found no evidence of association of OPRM1 A118G polymorphism and treatment success on any of the outcome measures [56]. Similar results were reported by Arias and colleagues in a cohort of alcohol dependent patients treated with nalmefene, a specific and potent opioid receptor antagonist that has affinity for the three opioid receptor subtypes (OPRM1, OPRD1 and OPRK1) [57]. In a total of 166 nalmefene treated alcohol dependent patiemts, the authors found no association of genetic variants, including OPRM1 $A 118 G$, with moderated response to nalmefene [57]. The lack of association reported in the latter study could be attributed to the fact that even though nalmefene is structurally similar to naltrexone, it differs in binding affinity for opioid receptors.

\begin{tabular}{|c|c|c|c|c|c|}
\hline Drug & $\begin{array}{c}\text { Gene } \\
\text { polymorphisms }\end{array}$ & $\begin{array}{l}\text { Subject } \\
\text { population }\end{array}$ & $\begin{array}{l}\text { Investigated } \\
\text { parameter }\end{array}$ & Primary outcome & $\begin{array}{l}\text { Refer- } \\
\text { ence }\end{array}$ \\
\hline \multirow[t]{5}{*}{ Naloxone } & OPRM1 A118G & $\begin{array}{l}39 \text { healthy } \\
\text { men treated } \\
\text { with five doses } \\
\text { of naloxone } \\
(0,50,100 \text {, } \\
200 \text { and } \\
400 \mu \mathrm{g} / \mathrm{kg} \text {, } \\
\text { incremental } \\
\text { doses per } 30 \\
\text { minutes })\end{array}$ & $\begin{array}{l}\text { Cortisol and } \\
\text { adrenocor- } \\
\text { ticotropin } \\
\text { release }\end{array}$ & $\begin{array}{l}\text { Carriers of OPRM1 } 118 G \\
\text { allele had: } \\
\text { - greater cortisol response } \\
\text { - different increase } \\
\text { adrenocorticotropin rate } \\
\text { (between } 30 \text { - } 90 \text { minutes) } \\
\text { - different decrease adre- } \\
\text { nocorticotropin rate (after } \\
90 \text { minutes) }\end{array}$ & [29] \\
\hline & & $\begin{array}{l}30 \text { healthy } \\
\text { individuals } \\
\text { treated with } \\
\text { intravenous } \\
\text { naloxone } 125 \\
\mu \mathrm{g} / \mathrm{kg}\end{array}$ & $\begin{array}{l}\text { Cortisol and } \\
\text { adrenocor- } \\
\text { ticotropin } \\
\text { release }\end{array}$ & $\begin{array}{l}\text { Carriers of OPRM1 } 118 G \\
\text { allele had: } \\
\text { - higher cortisol concentra- } \\
\text { tion (baseline and after } \\
\text { naloxone infusion) } \\
\text { - greater peak cortisol } \\
\text { response } \\
\text { - greater area under the } \\
\text { cortisol time curve }\end{array}$ & [30] \\
\hline & & $\begin{array}{l}74 \text { individu- } \\
\text { als receiving } \\
\text { five increas- } \\
\text { ing doses of } \\
\text { naloxone }(0, \\
50,100,200 \\
\text { and } 400 \mu \mathrm{g} / \\
\mathrm{kg} \text {, incremen- } \\
\text { tal doses per } \\
30 \text { minutes) }\end{array}$ & $\begin{array}{l}\text { Cortisol and } \\
\text { adrenocor- } \\
\text { ticotropin } \\
\text { release }\end{array}$ & $\begin{array}{l}\text { Carriers of OPRM1 } 118 G \\
\text { allele had: } \\
\text { - increased cortisol re- } \\
\text { sponse }\end{array}$ & {$[31]$} \\
\hline & & $\begin{array}{l}32 \text { non-treat- } \\
\text { ment seeking } \\
\text { hazardous } \\
\text { drinkers re- } \\
\text { ceiving } 50 \mathrm{mg} \\
\text { naltrexone }\end{array}$ & $\begin{array}{l}\text { Allopreg- } \\
\text { nanolole } \\
\text { and cortisol } \\
\text { levels }\end{array}$ & $\begin{array}{l}\text { Carriers of OPRM1 } 118 G \\
\text { allele had: } \\
\text { - increased allopregnano- } \\
\text { lole levels }\end{array}$ & [32] \\
\hline & & $\begin{array}{l}38 \text { students } \\
\text { with moder- } \\
\text { ate or heavier } \\
\text { drinking pat- } \\
\text { tern intrave- } \\
\text { nously receiv- } \\
\text { ing alcohol }\end{array}$ & $\begin{array}{l}\text { Alcohol } \\
\text { induced } \\
\text { sedation, } \\
\text { stimulation, } \\
\text { subjective } \\
\text { response, } \\
\text { mood altera- } \\
\text { tions }\end{array}$ & $\begin{array}{l}\text { Carriers of OPRM1 } 118 G \\
\text { allele had: } \\
\text {-greater feelings of intoxi- } \\
\text { cation } \\
\text { - higher increases in alco- } \\
\text { hol induced stimulation } \\
\text { - higher increases in state } \\
\text { happiness }\end{array}$ & [33] \\
\hline
\end{tabular}

Table 2. Human studies on the association of genetic polymorphisms with response to the opioid receptor antagonists naloxone and naltrexone. 


\begin{tabular}{|c|c|c|c|c|c|}
\hline \multirow{3}{*}{\multicolumn{2}{|c|}{ Naltrexone }} & $\begin{array}{l}40 \text { non-treat- } \\
\text { ment seeking } \\
\text { heavy drinkers } \\
\text { receiving } \\
\text { naltrexone } \\
50 \mathrm{mg} \text { for } \\
\text { three days and } \\
\text { intravenously } \\
\text { administered } \\
\text { alcohol }\end{array}$ & $\begin{array}{l}\text { Alcohol } \\
\text { sensitivity, } \\
\text { subjective } \\
\text { response } \\
\text { to alcohol, } \\
\text { craving }\end{array}$ & $\begin{array}{l}\text { Carriers of OPRM1 } 118 G \\
\text { allele had: } \\
\text { - higher increases in alco- } \\
\text { hol induced euphoria } \\
\text { - reduced alcohol induced } \\
\text { euphoria when receiving } \\
\text { naltrexone }\end{array}$ & [34] \\
\hline & & $\begin{array}{l}71 \text { naltrexone } \\
\text { treated ( } 50 \\
\text { or } 100 \mathrm{mg} / \\
\text { day for } 12 \\
\text { weeks) alcohol } \\
\text { dependent } \\
\text { individuals } \\
59 \text { placebo } \\
\text { treated indi- } \\
\text { viduals }\end{array}$ & $\begin{array}{l}\text { Clinical } \\
\text { response to } \\
\text { naltrexone } \\
\text { (relapse, } \\
\text { abstinence) }\end{array}$ & $\begin{array}{l}\text { Carriers of OPRM1 } 118 G \\
\text { allele had: } \\
\text { - greater chance not to } \\
\text { return to heavy drinking } \\
\text { - longer time to first } \\
\text { relapse }\end{array}$ & [35] \\
\hline & & $\begin{array}{l}300 \text { alcohol } \\
\text { dependent } \\
\text { patients } \\
\text { treated with } \\
\text { naltrexone } 50 \\
\text { or } 100 \mathrm{mg} / \text { day } \\
\text { for } 16 \text { weeks }\end{array}$ & $\begin{array}{l}\text { Clinical } \\
\text { response to } \\
\text { naltrexone } \\
\text { (abstinence, } \\
\text { heavy drink- } \\
\text { ing days, } \\
\text { adverse } \\
\text { events) }\end{array}$ & $\begin{array}{l}\text { Carriers of OPRM1 } 118 G \\
\text { allele had: } \\
\text { - an increasing trend in } \\
\text { abstinent days } \\
\text { - fewer heavy drinking days } \\
\text { - the best clinical outcome }\end{array}$ & [36] \\
\hline & $\begin{array}{l}\text { OPRM1 A118G, } \\
\text { DRD1 D2/D1, } \\
\text { DRD2 TaqI A2/ } \\
\text { A1, GRIN2B } \\
\text { C2664T, GA- } \\
\text { BRA6T1519C, } \\
\text { GABRB2 } \\
\text { C1421T, GA- } \\
\text { BRG2 G3145A }\end{array}$ & $\begin{array}{l}\text { - } 56 \text { acampro- } \\
\text { sate treated } \\
\text { and } \\
-52 \text { naltrex- } \\
\text { one treated } \\
-30 \text { placebo } \\
\text { treated alco- } \\
\text { hol dependent } \\
\text { patients }\end{array}$ & $\begin{array}{l}\text { Subjective } \\
\text { craving, } \\
\text { physiological } \\
\text { cue reactiv- } \\
\text { ity outcome } \\
\text { (heart rate) }\end{array}$ & $\begin{array}{l}\text { In carriers of OPRM1 } 118 G \\
\text { allele: } \\
\text { - naltrexone outperformed } \\
\text { acamprosate }\end{array}$ & [37] \\
\hline & OPRM1 A118G & $\begin{array}{l}146 \text { alcohol } \\
\text { dependent } \\
\text { patients } \\
\text { treated with } \\
\text { naltrexone } \\
100 \mathrm{mg} / \text { day for } \\
16 \text { weeks }\end{array}$ & $\begin{array}{l}\text { Clinical } \\
\text { response to } \\
\text { naltrexone } \\
\text { (abstinence, } \\
\text { heavy drink- } \\
\text { ing days, } \\
\text { adverse } \\
\text { events) }\end{array}$ & $\begin{array}{l}\text { Carriers of OPRM1 } 118 G \\
\text { allele had: } \\
\text { - good clinical outcome }\end{array}$ & [38] \\
\hline & & $\begin{array}{l}63 \text { alcohol } \\
\text { dependent pa- } \\
\text { tients treated } \\
\text { with naltrex- } \\
\text { one } 25 \mathrm{mg} / \text { day } \\
\text { for first } 3 \text { days } \\
\text { and } 50 \mathrm{mg} / \text { day } \\
\text { for remaining } \\
\text { days of a } 12 \\
\text { week treat- } \\
\text { ment }\end{array}$ & $\begin{array}{l}\text { Clinical } \\
\text { response to } \\
\text { naltrexone } \\
\text { (abstinence } \\
\text { rate, relapse } \\
\text { rate, time } \\
\text { to relapse) }\end{array}$ & $\begin{array}{l}\text { Carriers of OPRM } 1118 G \\
\text { allele had: } \\
\text { - longer time to relapse }\end{array}$ & [39] \\
\hline & & $\begin{array}{l}40 \text { social } \\
\text { drinkers } \\
\text { treated with } \\
\text { naltrexone } \\
25 \mathrm{mg} / \text { day for } \\
\text { first day and } \\
50 \mathrm{mg} / \text { day for } \\
\text { remaining } 5 \\
\text { days }\end{array}$ & $\begin{array}{l}\text { Subjective } \\
\text { effects of } \\
\text { alcohol }\end{array}$ & $\begin{array}{l}\text { Carriers of OPRM1 } 118 G \\
\text { allele had: } \\
\text { - decreased euphoria dur- } \\
\text { ing naltrexone treatment } \\
\text { after seeing and drinking } \\
\text { alcohol }\end{array}$ & [40] \\
\hline
\end{tabular}




\begin{tabular}{|c|c|c|c|c|}
\hline & \begin{tabular}{l|}
5 non treat- \\
ment seeking \\
heavy drinkers \\
treated with \\
naltrexone \\
$25 \mathrm{mg}$ for 2 \\
days and $50 \mathrm{mg}$ \\
for 2 days)
\end{tabular} & $\begin{array}{l}\text { Clinical } \\
\text { response to } \\
\text { naltrexone } \\
\text { (intoxica- } \\
\text { tion, crav- } \\
\text { ing) }\end{array}$ & $\begin{array}{l}\text { Carriers of OPRM1 } 118 G \\
\text { allele had: } \\
\text { - greater alcohol induced } \\
\text { sedation and intoxication } \\
\text { - lower craving for alcohol }\end{array}$ & [41] \\
\hline & $\begin{array}{l}112 \text { prob- } \\
\text { lem drinkers } \\
\text { treated with } \\
\text { naltrexone } \\
100 \mathrm{mg} / \text { day for } \\
12 \text { weeks }\end{array}$ & $\begin{array}{l}\text { Clinical } \\
\text { response to } \\
\text { naltrexone } \\
\text { (non hazard- } \\
\text { ous drinking) }\end{array}$ & $\begin{array}{l}\text { Carriers of OPRM1 } 118 G \\
\text { allele had: } \\
\text { - increased percentage of } \\
\text { non-hazardous drinking }\end{array}$ & [42] \\
\hline & $\begin{array}{l}90 \text { individu- } \\
\text { als (mixed } \\
\text { population of } \\
\text { non treatment } \\
\text { seeking alco- } \\
\text { hol dependent } \\
\text { individuals } \\
\text { and non alco- } \\
\text { hol dependent } \\
\text { individuals), } \\
42 \text { of them } \\
\text { treated with } \\
\text { naltrexone } \\
50 \text { mg/day for } \\
3 \text { weeks and } \\
48 \text { on placebo }\end{array}$ & $\begin{array}{l}\text { Urge to } \\
\text { drink }\end{array}$ & $\begin{array}{l}\text { Carriers of OPRM1 } 118 G \\
\text { allele had: } \\
\text { - increased urge to drink } \\
\text { when receiving naltrexone } \\
\text { compared to placebo }\end{array}$ & [43] \\
\hline & $\begin{array}{l}81 \text { problem } \\
\text { drinkers } \\
\text { receiving } \\
\text { naltrexone } \\
50 \mathrm{mg} / \text { day for } \\
2 \text { weeks }\end{array}$ & $\begin{array}{l}\text { Drinking } \\
\text { attenuation } \\
\text { by naltrex- } \\
\text { one (desire } \\
\text { to drink, } \\
\text { subsequent } \\
\text { drinking) }\end{array}$ & $\begin{array}{l}\text { Carriers of OPRM1 } 118 G \\
\text { allele had: } \\
\text { - stronger evening desire } \\
\text { to drink } \\
\text { - greater risk of drinking } \\
\text { more }\end{array}$ & [44] \\
\hline $\begin{array}{l}\text { OPRM1 } \\
\text { A118G, OPRK1 } \\
\text { rs997917 \& } \\
\text { rs6985606, } \\
\text { OPRD1 } \\
\text { rs4654327, } \\
\text { rs2236856, } \\
\text { rs499062, } \\
\text { rs678849\& } \\
\text { rs508448 }\end{array}$ & $\begin{array}{l}40 \text { heavy } \\
\text { drinkers re- } \\
\text { ceiving } 50 \mathrm{mg} \\
\text { naltrexone } \\
\text { for } 3 \text { days and } \\
\text { undergoing } \\
\text { intravenous } \\
\text { alcohol chal- } \\
\text { lenge }\end{array}$ & $\begin{array}{l}\text { Subjective } \\
\text { response } \\
\text { to alcohol, } \\
\text { craving }\end{array}$ & $\begin{array}{l}\text { OPRK1 rs } 997919 \text { and OPRD1 } \\
\text { rs4654327 polymorphisms } \\
\text { were associated with } \\
\text { response to alcohol after } \\
\text { controlling for OPRM1 } \\
\text { A118G polymorphism }\end{array}$ & [46] \\
\hline $\begin{array}{l}\text { OPRM1 A118G, } \\
\text { DAT } 9 \text { VNTR }\end{array}$ & $\begin{array}{l}83 \text { non treat- } \\
\text { ment seeking } \\
\text { alcohol depen- } \\
\text { dent individu- } \\
\text { als receiving } \\
\text { placebo or } \\
\text { naltrexone } \\
25 \mathrm{mg} / \text { day for } \\
2 \text { days and } \\
50 \mathrm{mg} / \text { day for } \\
5 \text { days }\end{array}$ & $\begin{array}{l}\text { Response to } \\
\text { naltrexone } \\
\text { (number } \\
\text { of drinks, } \\
\text { heavy drink- } \\
\text { ing days, } \\
\text { alcohol } \\
\text { stimulation) }\end{array}$ & $\begin{array}{l}\text { Non carriers of OPRM1 } \\
118 G \text { allele and carriers of } \\
\text { DAT } 9 \text { VNTR had: } \\
\text { - more stimulation to } \\
\text { alcohol } \\
\text { - reduced number of drinks } \\
\text { when on naltrexone treat- } \\
\text { ment }\end{array}$ & [47] \\
\hline & $\begin{array}{l}74 \text { non treat- } \\
\text { ment seeking } \\
\text { alcohol depen- } \\
\text { dent individu- } \\
\text { als receiving } \\
\text { placebo or } \\
\text { naltrexone } \\
50 \mathrm{mg} / \text { day for } \\
1 \text { week }\end{array}$ & $\begin{array}{l}\text { Alcohol cue } \\
\text { elicited rain } \\
\text { activation }\end{array}$ & $\begin{array}{l}\text { Carriers of OPRM } 1118 G \text { al- } \\
\text { lele and carriers of DAT } 10 \\
\text { VNTR had: } \\
\text { - less stimulation to alcohol }\end{array}$ & [48] \\
\hline
\end{tabular}




\begin{tabular}{|c|c|c|c|c|c|}
\hline & & $\begin{array}{l}43 \text { non treat- } \\
\text { ment seeking } \\
\text { alcohol } \\
\text { dependent } \\
\text { individuals }\end{array}$ & $\begin{array}{l}\text { Subjective } \\
\text { response to } \\
\text { alcohol }\end{array}$ & $\begin{array}{l}\text { Carriers of OPRM1 } 118 G \text { al- } \\
\text { lele and carriers of DAT } 10 \\
\text { VNTR had: } \\
\text { - steeper increase in stimu- } \\
\text { lation to alcohol } \\
\text { - steeper increase in posi- } \\
\text { tive mood }\end{array}$ & [49] \\
\hline & $\begin{array}{l}\text { OPRM1 A118G } \\
\text { (Meta analysis) }\end{array}$ & $\begin{array}{l}6 \text { studies: } 453 \\
\text { naltrexone } \\
\text { treated alco- } \\
\text { hol dependent } \\
\text { patients }\end{array}$ & $\begin{array}{l}\text { Response to } \\
\text { naltrexone } \\
\text { (relapse } \\
\text { rate, ab- } \\
\text { stienence } \\
\text { rate }\end{array}$ & $\begin{array}{l}\text { Carriers of OPRM1 } 118 G \\
\text { allele had: } \\
\text { - lower relapse rate }\end{array}$ & [51] \\
\hline & OPRM1 A118G & $\begin{array}{l}215 \text { alcohol } \\
\text { dependent } \\
\text { male patients } \\
\text { treated with } \\
\text { naltrexone } \\
50 \mathrm{mg} / \text { day for } \\
3 \text { to } 12 \text { months }\end{array}$ & $\begin{array}{l}\text { Naltrexone } \\
\text { response } \\
\text { (relapse } \\
\text { rate, time } \\
\text { to relapse, } \\
\text { drinks per } \\
\text { drinking } \\
\text { day) }\end{array}$ & $\begin{array}{l}\text { No association of OPRM1 } \\
118 G \text { polymorphism with } \\
\text { investigated parameter }\end{array}$ & [52] \\
\hline & & $\begin{array}{l}25 \text { alcohol } \\
\text { dependent pa- } \\
\text { tients treated } \\
\text { with naltrex- } \\
\text { one } 50 \mathrm{mg} / \text { day }\end{array}$ & $\begin{array}{l}\text { Self report- } \\
\text { ed ethanol } \\
\text { consumption }\end{array}$ & $\begin{array}{l}\text { No association of OPRM1 } \\
118 G \text { polymorphism with } \\
\text { investigated parameter }\end{array}$ & [53] \\
\hline & & $\begin{array}{l}101 \text { alcohol } \\
\text { dependent } \\
\text { patients } \\
\text { treated with } \\
\text { naltrexone } \\
\text { monotherapy } \\
50 \mathrm{mg} / \text { day or } \\
\text { naltrexone } \\
\text { and } 50 \mathrm{mg} / \text { day } \\
\text { and sertraline } \\
100 \mathrm{mg} \text { com- } \\
\text { bined therapy } \\
\text { or placebo for } \\
16 \text { weeks }\end{array}$ & $\begin{array}{l}\text { Naltrexone } \\
\text { response } \\
\text { (drinking } \\
\text { behavior, } \\
\text { craving) }\end{array}$ & $\begin{array}{l}\text { No association of OPRM1 } \\
118 G \text { polymorphism with } \\
\text { investigated parameter, } \\
\text { analyses were restricted in } \\
\text { OPRM1 } 118 A A \text { individuals }\end{array}$ & [54] \\
\hline & & $\begin{array}{l}180 \text { heavy } \\
\text { drinkers ( } 63 \% \\
\text { alcohol de- } \\
\text { pendent), } 88 \\
\text { treated with } \\
\text { naltrexone } \\
50 \mathrm{mg} / \text { day for } \\
3 \text { weeks }\end{array}$ & $\begin{array}{l}\text { Naltrexone } \\
\text { response } \\
\text { (urge for al- } \\
\text { cohol, time } \\
\text { between } \\
\text { drinks, alco- } \\
\text { hol effects) }\end{array}$ & $\begin{array}{l}\text { No association of OPRM1 } \\
118 G \text { polymorphism with } \\
\text { investigated parameter }\end{array}$ & [55] \\
\hline & & $\begin{array}{l}100 \text { alcohol } \\
\text { dependent pa- } \\
\text { tients treated } \\
\text { with naltrex- } \\
\text { one } 50 \mathrm{mg} / \text { day } \\
\text { for } 12 \text { weeks }\end{array}$ & $\begin{array}{l}\text { Naltrexone } \\
\text { response } \\
\text { (relapse } \\
\text { rate, time } \\
\text { to relapse, } \\
\text { craving, } \\
\text { adverse } \\
\text { events, } \\
\text { treatment } \\
\text { retention) }\end{array}$ & $\begin{array}{l}\text { No association of OPRM1 } \\
\text { A118G polymorphism with } \\
\text { investigated parameter }\end{array}$ & [56] \\
\hline Nalmefene & OPRM1 A118G & $\begin{array}{l}166 \text { alcohol } \\
\text { dependent } \\
\text { patients with } \\
\text { nalmefene } 28 \\
\text { weeks } 20 \text { or } 40 \\
\text { mg/day for }\end{array}$ & $\begin{array}{l}\text { Nalmefene } \\
\text { efficacy and } \\
\text { safety }\end{array}$ & $\begin{array}{l}\text { No association of OPRM1 } \\
\text { A118G polymorphism with } \\
\text { investigated parameter }\end{array}$ & [57] \\
\hline
\end{tabular}


The association of OPRM1 gene polymorphisms with naltrexone response is the subject of several clinical trials (Table 3). Clinical trial NCT00920829 assesses the effect of OPRM1 A118G gene polymorphism on treatment response to naltrexone in treatmentseeking alcohol dependent patients treated with 25 or $50 \mathrm{mg}$ naltrexone. Response will be measured by the percent of heavy drinking days and days of abstinence. Additional primary outcome is the potential difference in the naltrexone dampening of the alcohol cue-induced brain activation dependent on OPRM1 genotype. Medication compliance and side effects based on OPRM1 genotype will also be assessed.In clinical trial NCT02026011 the pharmacogenomic effects of OPRM1 A118G genepolymorphism on biobehavioral and neural markers of response to naltrexone $(50 \mathrm{mg} /$ day) in individuals of East Asian descent is assessed. Clinical trials NCT01738867 and NCT00817089 have been completed but results have not been annotated yet. In clinical trial NCT01738867 at least 48 healthy subjects with a history of social drinking would be recruited and genetically be stratified to result in equal numbers of $A 118 G^{\prime} A A^{\prime}$ homozygotes and $A 118 G^{\prime} G^{\prime}$ carriers for a 5 days treatment with placebo, naltrexone or GSK1521498, a novel opioid antagonist being investigated as a candidate treatment for behavioral and substance addictions. In naltrexone treatment arm, individuals would receive $25 \mathrm{mg}$ for the first two days and 50mg for the rest 3 days. Outcomes include functional brain response to alcohol, plasma cortisol and subjective response to an ethanol challenge. In clinical trial NCT00817089, males of European or Asian decent following two inpatient alcohol challenge sessions along with 12 weeks of outpatient treatment using random assignment to either naltrexone $(100 \mathrm{mg} /$ day) or placebo, were recruited. The relationship between OPRM1 A118G polymorphism and the subjective/objective measures to alcohol among alcohol dependent patients treated with naltrexone was

\begin{tabular}{|c|c|c|c|c|c|c|}
\hline $\begin{array}{l}\text { Examined } \\
\text { drug }\end{array}$ & $\begin{array}{c}\text { Gene } \\
\text { polymorphisms }\end{array}$ & $\begin{array}{c}\text { Clinical trial } \\
\text { Assession } \\
\text { number }\end{array}$ & Status & Population & $\begin{array}{l}\text { Clinical trial } \\
\text { examined } \\
\text { Outcome }\end{array}$ & $\begin{array}{l}\text { Published } \\
\text { results }\end{array}$ \\
\hline \multirow[t]{2}{*}{ Naltrexone } & \multirow[t]{2}{*}{ OPRM1 A118G } & NCT00006206 & Completed & $\begin{array}{l}300 \text { alcohol } \\
\text { dependent } \\
\text { patients } \\
\text { randomized } \\
\text { on naltrex- } \\
\text { one }\end{array}$ & $\begin{array}{l}\text { Percent days } \\
\text { abstinent, time } \\
\text { to relapse to } \\
\text { heavy drink- } \\
\text { ing, measures } \\
\text { of drinking } \\
\text { outcomes } \\
\text { and adverse } \\
\text { exoesirences, } \\
\text { psychological } \\
\text { assessments } \\
\text { and quality of } \\
\text { life }\end{array}$ & $\begin{array}{l}\text { Carriers } \\
\text { of OPRM1 } \\
118 G \\
\text { allele } \\
\text { showed an } \\
\text { increasing } \\
\text { trend in } \\
\text { abstinent } \\
\text { days over } \\
\text { time, few- } \\
\text { er heavy } \\
\text { drinking } \\
\text { days over } \\
\text { time and } \\
\text { the best } \\
\text { outcome } \\
\text { [36] }\end{array}$ \\
\hline & & NCT00369408 & Completed & $\begin{array}{l}81 \text { problem } \\
\text { drinkers on } \\
\text { naltrexone } \\
50 \mathrm{mg} / \text { day }\end{array}$ & $\begin{array}{l}\text { Drinking } \\
\text { days, heavy } \\
\text { drinking days, } \\
\text { alcohol-related } \\
\text { problems and } \\
\text { biological mea- } \\
\text { sures of alcohol } \\
\text { consumption }\end{array}$ & $\begin{array}{l}\text { Carriers } \\
\text { of OPRM1 } \\
118 G \\
\text { allele } \\
\text { showed a } \\
\text { stronger } \\
\text { evening } \\
\text { drinking } \\
\text { desire and } \\
\text { were at } \\
\text { greater } \\
\text { risk of } \\
\text { drinking } \\
\text { more than } \\
118 A A \text { ho- } \\
\text { mozygotes } \\
\text { [44] }\end{array}$ \\
\hline
\end{tabular}

Table 3. Clinical trials assessing the pharmacogenomics of alcohol dependence drugs 


\begin{tabular}{|c|c|c|c|c|c|c|}
\hline & & NCT00920829 & Recruiting & $\begin{array}{l}\text { Treatment } \\
\text { seeking } \\
\text { alcoholic } \\
\text { patients } \\
\text { treated } \\
\text { with } 25 \text { or } \\
50 \mathrm{mg} \text { nal- } \\
\text { trexone }\end{array}$ & $\begin{array}{l}\text { Percent heavy } \\
\text { drinking days, } \\
\text { adverse ef- } \\
\text { fects, drinks } \\
\text { per drink- } \\
\text { ing day and } \\
\text { percent days } \\
\text { abstinent }\end{array}$ & N.A. \\
\hline & & NCT02026011 & Recruiting & $\begin{array}{l}\text { Individu- } \\
\text { als of East } \\
\text { Asian } \\
\text { descent } \\
\text { treated } \\
\text { with } \\
\text { naltrexone } \\
50 \mathrm{mg} / \text { day }\end{array}$ & $\begin{array}{l}\text { Subjective } \\
\text { effects of } \\
\text { alcohol, neural } \\
\text { response to } \\
\text { alcohol cues, } \\
\text { time to first } \\
\text { drink and total } \\
\text { number of } \\
\text { drinks }\end{array}$ & N.A. \\
\hline & & NCT01738867 & Completed & $\begin{array}{l}\text { A total of } \\
\text { at least } \\
48 \text { healthy } \\
\text { subjects } \\
\text { with a } \\
\text { history } \\
\text { of social } \\
\text { drinking } \\
\text { treated } \\
\text { with nal- } \\
\text { trexone } 25 \\
\text { mg orally } \\
\text { once daily } \\
\text { for the first } \\
\text { two days } \\
\text { and } 50 \text { mg } \\
\text { once daily } \\
\text { for } 3 \text { days }\end{array}$ & $\begin{array}{l}\text { Brain activa- } \\
\text { tion within } \\
\text { the reward } \\
\text { circuitry in } \\
\text { response to } \\
\text { consumption } \\
\text { of food and } \\
\text { alcohol cues, } \\
\text { adverse events, } \\
\text { safety and } \\
\text { tolerability, } \\
\text { plasma cortisol } \\
\text { concentrations, } \\
\text { subjective } \\
\text { responses to } \\
\text { i.v. doses of } \\
\text { ethanol }\end{array}$ & N.A. \\
\hline & & NCT00817089 & Completed & $\begin{array}{l}\text { Alcohol } \\
\text { dependent } \\
\text { males of } \\
\text { European } \\
\text { or Asian } \\
\text { decent } \\
\text { treated } \\
\text { with } \\
\text { naltrexone } \\
50 \mathrm{mg} / \\
\text { day for } 12 \\
\text { weeks }\end{array}$ & $\begin{array}{l}\text { Differences } \\
\text { between the } \\
\text { peak cortisol } \\
\text { response and } \\
\text { subjective } \\
\text { response, } \\
\text { improvement } \\
\text { in quality of } \\
\text { life, biologi- } \\
\text { cal markers of } \\
\text { heavy drinking }\end{array}$ & N.A. \\
\hline Acamprosate & $\begin{array}{l}\text { GRIN1, GRIN2A, } \\
\text { GRIN2B, } \\
\text { mGluR5 }\end{array}$ & NCT00662571 & Completed & & & N.A. \\
\hline Topiramate & $\begin{array}{l}\text { Candidate } \\
\text { genes are not } \\
\text { defined }\end{array}$ & NCT00884884 & Unknown & $\begin{array}{l}216 \text { non- } \\
\text { treatment } \\
\text { seeking, } \\
\text { alcohol } \\
\text { dependent } \\
\text { individu- } \\
\text { als treated } \\
\text { with } \\
\text { topiramate } \\
100 \mathrm{mg} / \mathrm{day} \\
\text { or } 200 \mathrm{mg} / \\
\text { day alone } \\
\text { or in combi- } \\
\text { nation with } \\
\text { aripiprazole } \\
7.5 \mathrm{mg} / \mathrm{day} \\
\text { or } 115 \mathrm{mg} / \\
\text { day }\end{array}$ & $\begin{array}{l}\text { Drinking and } \\
\text { safety, clinical } \\
\text { and behavioral } \\
\text { effects }\end{array}$ & N.A. \\
\hline
\end{tabular}


tested.

OPRM1 A118G polymorphism is associated with naltrexone response with a high degree of reproducibility and has emerged as a useful genetic marker in personalizing naltrexone treatment. Results from prospective, randomized clinical trials on the association of OPRM1 A118G polymorphism with naltrexone response will enable the clinical application of naltrexone pharmacogenomics in routine clinical practice.

\section{Acamprosate}

Acamprosate has been approved to maintain abstinence in alcohol dependent individuals who have quit drinking. Acamprosate does not prevent the withdrawal symptoms people may experience when they stop drinking alcohol, but reduces craving for alcohol and relapse after quitting drinking. The exact mechanism of action of acamprosate is still unknown, however, it has been suggested that it interferes with the glutamate system, leading to neurotransmitter balance restoration that is disturbed after chronic alcohol abuse [58]. Overall, the adoption of acamprosate in alcohol addiction treatment is limited [59]. This might be the major factor that even though only one third of individuals receiving acamprosate remain alcohol abstinent for more than six months, data on acamprosate pharmacogenomics are scarce.

The potential association of genetic variations with acamprosate response has been assessed only in one study (Table 4); Ooteman and colleagues have tested the differential effects on acamprosate and naltrexone on reductions in cue-induced craving and physiological cue reactivity for different polymorphisms on the opioid, dopamine, glutamate and $\gamma$-aminobutyric acid (GABA) receptors [37]. The authors have found that acamprosate efficacy was enhanced in GABRA6 $1519 \mathrm{C}$ allele carriers and that in GABRB2 1412TT homozygous individuals acamprosate outperformed naltrexone with respect to physiological cue reactivity (heart rate), and in DRD2 A1A1 homozygous acamprosate outperformed naltrexone with respect to craving as measured with a visual analogue scale [37]. The minor allele frequency of the described gene polymorphisms and their effect on protein are presented in Table 1.

\begin{tabular}{|c|c|c|c|c|c|}
\hline Drug & $\begin{array}{c}\text { Gene } \\
\text { polymorphisms }\end{array}$ & $\begin{array}{c}\text { Subject } \\
\text { population }\end{array}$ & $\begin{array}{l}\text { Investigated } \\
\text { parameter }\end{array}$ & Primary outcome & Reference \\
\hline Acamprosate & $\begin{array}{l}\text { OPRM1 A118G, } \\
\text { DRD1 D2/D1, } \\
\text { DRD2 TaqI A2/A1, } \\
\text { GRIN2B C2664T, } \\
\text { GABRA6T1519C, } \\
\text { GABRB2 C1421T, } \\
\text { GABRG2 G3145A }\end{array}$ & $\begin{array}{l}\text { - } 56 \text { acamprosate } \\
\text { treated and } \\
\text { - } 52 \text { naltrexone } \\
\text { treated } \\
\text { - } 30 \text { placebo } \\
\text { treated alco- } \\
\text { hol dependent } \\
\text { patients }\end{array}$ & $\begin{array}{l}\text { Subjective } \\
\text { craving, } \\
\text { physiological } \\
\text { cue reactiv- } \\
\text { ity outcome } \\
\text { (heart rate) }\end{array}$ & $\begin{array}{l}\text { - Acamprosate } \\
\text { efficacy was en- } \\
\text { hanced in GABRA6 } \\
1519 C \text { allele } \\
\text { carriers } \\
\text { - In GABRB2 } \\
1412 T T \text { individu- } \\
\text { als acamprosate } \\
\text { outperformed nal- } \\
\text { trexone (param- } \\
\text { eter measured: } \\
\text { physiological cue } \\
\text { reactivity - heart } \\
\text { rate) } \\
\text { - In DRD2 A1A1 } \\
\text { individuals, } \\
\text { acamprosate } \\
\text { outperformed nal- } \\
\text { trexone (param- } \\
\text { eter measured: } \\
\text { craving) }\end{array}$ & [37] \\
\hline
\end{tabular}

Currently, one clinical trial assessing the effect of genetic variations on acamprosate response is registered on the ClinicalTrials. gov website (listed in Table 3). Clinical trial NCT00662571, assessing the effect of polymorphisms in GRIN1, GRIN2A and GRIN2B genes coding for N-methyl-D-aspartate receptor (NMDA) and type 5 metabotropic glu- tamate receptor (mGluR5) on acamprosate response has been completed; however, the results have not been published yet.

Pharmacogenomics may have the potential to guide therapy of acamprosate, by increasing drug therapeutic success and days of abstinence. However, data is still lacking. Therefore, more studies should be conducted
Table 4. Human studies on the association of genetic polymorphisms with response to acamprosate 
to assess the effect of genetic variations on acamprosate response.

\section{Disulfiram}

Disulfiram reduces alcohol dependence by inhibiting the enzyme aldehyde dehydrogenase leading to increased plasma levels of acetaldehyde upon drinking alcohol, a byproduct of alcohol metabolism that is aversive [60]. Disul$(\mathrm{D} \beta \mathrm{H})$, the enzyme that converts dopamine into norepinephrine and is co-released with catecholamines [61]. Polymorphisms in $\mathrm{D} \beta \mathrm{H}$ gene affect circulating $\mathrm{D} \beta \mathrm{H}$ levels. Specifically, $C-1021 T$ polymorphism, positioned $\sim 1 \mathrm{~kb}$ upstream from the initiation codon of the $D \beta H$ gene, is associated with decreased $\mathrm{D} \beta \mathrm{H}$ levels. Individuals that are $-1021 T$ allele homozygous have the lowest levels of plasma $\mathrm{D} \beta \mathrm{H}$ activity [62]. One could speculate that, in individuals with already low levels of $\mathrm{D} \beta \mathrm{H}$ enzyme due to $C-1021 T$ polymorphism, disulfiram would be more effective in increasing dopamine and decreasing norepinephrine, therefore carriage of $-1021 T$ allele can potentially be associated with increased response to disulfiram therapy.

It has been suggested that individu-

Table 5. Human studies on the association of genetic polymorphisms with response to disulfiram. firam also inhibits dopamine beta-hydroxylase

als carrying $D \beta H C$-1021T TT genotype would respond better to disulfiram treatment and would need less of a dose whereas CT individuals would need an intermediate dose and those with the CC genotype may need increased concentrations for maximum therapeutic effectiveness [63]. For disulfiram, only one study has assessed the effect of $D \beta H C-1021 T$ polymorphism on treatment response (Table 5) [64]. In this study, Mutschler and colleagues have recruited 62 alcohol-dependent patients from the specialized disulfiram outpatient treatment program in Mannheim, Germany. The authors have found that carrying $D \beta H-1021 T$ low activity allele is associated with an increased risk of adverse events, but not with disulfiram response, despite a trend of longer cumulative alcohol abstinence achieved in CT/TT individuals, compared to $C C$ group [64]. It should be noted, however, that,currently,disulfiram is not a treatment of choice for alcohol dependence due to the increased number and fear of the severe and sometimes fatal reaction known as a disulfiram-alcohol reaction. Disulfiramalcohol reaction is the result of the build up of a chemical from the alcohol in the body when patients take the medicine and drink alcohol at

\begin{tabular}{|c|c|c|c|c|c|}
\hline Drug & $\begin{array}{c}\text { Gene } \\
\text { polymorphisms }\end{array}$ & $\begin{array}{c}\text { Subject } \\
\text { population }\end{array}$ & $\begin{array}{l}\text { Investigated } \\
\text { parameter }\end{array}$ & Primary outcome & Reference \\
\hline Disulfiram & DBH C-1021T & $\begin{array}{l}\text { - } 62 \text { disulfiram } \\
\text { treated alco- } \\
\text { hol dependent } \\
\text { patients }\end{array}$ & $\begin{array}{l}\text { Time until } \\
\text { first relapse, } \\
\text { accumu- } \\
\text { lated time of } \\
\text { abstinence, } \\
\text { craving, ad- } \\
\text { verse events, } \\
\text { treatment } \\
\text { safety and } \\
\text { tolerability }\end{array}$ & $\begin{array}{l}\text { Carriers of - } 1021 T \\
\text { allele had: } \\
\text { - increased risk of } \\
\text { adverse events } \\
\text { - a trend towards } \\
\text { longer cumulative } \\
\text { alcohol absti- } \\
\text { nence }\end{array}$ & [64] \\
\hline
\end{tabular}

the same time.

Currently, no clinical trials are registered at ClinicalTrials.gov on $\mathrm{D} \beta \mathrm{H}$ genetic variations and disulfiram response in alcohol dependent patients.

Disulfiram is currently rarely used for the treatment of alcohol dependence. Further pharmacogenomic studies that will unravel the genetic factors affecting disulfiram response are needed.

\section{Topiramate}

Topiramate is an anticonvulsant medication that has recently been identified as a potent therapy of alcohol dependence. Even though topiramate has not yet gained approval for alcohol dependence treatment, several controlled clinical trials have shown its efficacy in the treatment of alcohol dependence and it has been used in several countries for the treatment of alcohol dependence $[65,66]$. Topiramate may antagonize alcohol rewarding effects associated with abuse liability by inhibiting mesocorticolimbic dopamine release. Also, it has been suggested that it enhances the inhibitory function of GABA, antagonizes excitatory glutamate receptors, and inhibits dopamine release [67]. However, a major concern and limitation in the use of topiramate has been its adverse effects, which are prominent especially during the titration period, appear to be dose-related but usually subside 
with continued treatment [66]. Recently it has been reported that the $r s 2832407 C>A$ intron 9 polymorphism of glutamate receptor GluR5 (GRIK1) gene is associated with the severity of topiramate-induced side effects and with serum levels of topiramate, thus making it an interesting candidate for therapy personalization [68].

First evidence on the association of GRIK1 polymorphisms with topiramate pharmacokinetics and response were published on 2009 (Table 6). Ray and colleagues have shown that,in a total of 32 alcohol dependent patients treated with topiramate $200-300 \mathrm{mg} /$ day for 5 weeks, GRIK1 rs $2832407 C>A$ polymorphismwas associated with topiramate serum levels and the severity of topiramate-induced side effects [69]. Carriers of $r s 2832407 A$ al- lele had both higher serum topiramate levels and of greater severity topiramate side effects both when compared to placebo and to homozygous topiramate treated CC individuals. Additionally, carriers of $r s 2832407 \mathrm{~A}$ allele reported higher mean percentage of heavy drinking days as compared to $C C$ individuals (40.4\% vs. $22.2 \%)$ [69]. More recently, Kranzler and colleagues have analyzed the association of GRIK1 rs2832407C>A polymorphism with topiramate effect on heavy drinking days [70]. In a total of 138 individuals treated either with topiramate at a maximal dose of $200 \mathrm{mg}$ for 12 weeks (67 individuals) or matching placebo (71 individuals), the authors have found that, in a subgroup of 122 European American individuals the effect of topiramate on heavy drinking days was significantly greater than

\begin{tabular}{|c|c|c|c|c|c|}
\hline Drug & $\begin{array}{c}\text { Gene } \\
\text { polymorphisms }\end{array}$ & $\begin{array}{c}\text { Subject } \\
\text { population }\end{array}$ & $\begin{array}{l}\text { Investigated } \\
\text { parameter }\end{array}$ & Primary outcome & Reference \\
\hline \multirow[t]{4}{*}{ Topiramate } & $\begin{array}{l}\text { GRIK1 } \\
r s 2832407 C>A\end{array}$ & $\begin{array}{l}32 \text { non-treatment } \\
\text { seeking heavy } \\
\text { drinkers ( } 75 \% \text { al- } \\
\text { cohol dependent } \\
\text { patients) treated } \\
\text { with topiramate } \\
200-300 \mathrm{mg} / \text { day } \\
\text { for } 5 \text { weeks }\end{array}$ & $\begin{array}{l}\text { Severity } \\
\text { of adverse } \\
\text { events, } \\
\text { topiramate } \\
\text { serum levels, } \\
\text { drinking } \\
\text { behavior }\end{array}$ & $\begin{array}{l}\text { Carriers of } \\
\text { rs2832407A allele } \\
\text { had: } \\
\text { - Increased sever- } \\
\text { ity of adverse } \\
\text { events } \\
\text { - Higher mean } \\
\text { percentage of } \\
\text { heavy drinking } \\
\text { days } \\
\text { - Higher serum } \\
\text { topiramate levels }\end{array}$ & [69] \\
\hline & & $\begin{array}{l}67 \text { individuals } \\
\text { treated with } \\
\text { topiramate } \\
\text { 200mg for } 12 \\
\text { weeks and } 71 \\
\text { placebo treated } \\
\text { individuals }\end{array}$ & $\begin{array}{l}\text { Topiramate } \\
\text { efficacy and } \\
\text { tolerability }\end{array}$ & $\begin{array}{l}\text { In a subsample of } \\
122 \text { individuals, } \\
\text { the effect of topi- } \\
\text { ramate on heavy } \\
\text { drinking days } \\
\text { was significantly } \\
\text { greater than that } \\
\text { of placebo only } \\
\text { in rs } 2832407 C C \\
\text { homozygotes }\end{array}$ & [70] \\
\hline & & $\begin{array}{l}67 \text { individuals } \\
\text { treated with } \\
\text { topiramate } \\
200 \mathrm{mg} \text { for } 12 \\
\text { weeks and } 71 \\
\text { placebo treated } \\
\text { individuals }\end{array}$ & $\begin{array}{l}\text { Topiramate } \\
\text { effect on } \\
\text { body mass } \\
\text { index (BMI) }\end{array}$ & $\begin{array}{l}\text { In a subsample } \\
\text { of } 122 \text { individu- } \\
\text { als, no asso- } \\
\text { ciation of GRIK1 } \\
\text { rs } 2832407 C>A \\
\text { polymorphism was } \\
\text { found with inves- } \\
\text { tigated parameter }\end{array}$ & [71] \\
\hline & & $\begin{array}{l}67 \text { individuals } \\
\text { treated with } \\
\text { topiramate } \\
\text { 200mg for } 12 \\
\text { weeks and } 71 \\
\text { placebo treated } \\
\text { individuals }\end{array}$ & $\begin{array}{l}\text { Topiramate } \\
\text { response } \\
\text { (reduction } \\
\text { in drinking, } \\
\text { desire to } \\
\text { drink, posi- } \\
\text { tive alcohol } \\
\text { expectan- } \\
\text { cies) }\end{array}$ & $\begin{array}{l}\text { In a subsample } \\
\text { of } 122 \text { individu- } \\
\text { als, rs } 2832407 C C \\
\text { homozygotes: } \\
\text { - drank less during } \\
\text { treatment } \\
\text { - showed the } \\
\text { largest decreases } \\
\text { in positive alcohol } \\
\text { expectancies and } \\
\text { desire to drink }\end{array}$ & [72] \\
\hline
\end{tabular}

Table 6. Human studies on the association of genetic polymorphisms with response to topiramate 
that for placebo only in $r s 2832407 C C$ homozygotes [70]. The same research team have further analyzed in the subgroup of 122 European American individuals the potential association of GRIK1 rs2832407C >A polymorphism with topiramate effect on BMI, but no association was found [71]. Finally, Kranzler and colleagues have validated in the subgroup of 122 European American individuals the interactive effect of GRIK1 rs2832407C > A polymorphism and topiramate as predictors of drinking level [72]. The authors have found that topiramatetreated $r s 2832407 C C$ homozygotes drank less during treatment than those receiving placebo, validating this way their earlier findings, and have also shown that rs2832407CC homozygotes showed the largest decreases in positive alcohol expectancies and desire to drink [72].

Several clinical trials are registered on Clinicaltrials.gov website and assess whether topiramate will improve drinking outcomes in alcohol dependent individuals, however, currently, only one clinical trial assesses the association of gene polymorphisms with topiramate effect on craving, subjective stimulation and other behavioral effects associated with alcohol consumption (Table 3). The clinical trial NCT00884884 will recruit 216 healthy, alcohol-dependent volunteers who are not currently seeking treatment for their alcohol dependence to learn more about how topiramate and alprazolam medications may work on alcohol dependence and how gene polymorphisms modulate their action.

Topiramate appears to be a promising therapy for alcohol dependence. Accumulated data implicate consistently GRIK1 $r s 2832407 C>A$ as a predictor of topiramate response and adverse drug reactions incidence. Therefore, upon approval of topiramate as a therapy for alcohol dependence, GRIK1 polymorphisms may have an important role in personalizing topiramate therapy.

\section{Other drugs}

So far, as it was already extensively described, the only three drugs that have been approved by FDA for alcohol dependence are naltrexone, acamprosate and disulfiram, whereas topiramate appears as a promising therapy. Several other compounds have been experimented for the treatment of alcohol dependence and some of them are in clinical development. Describing the exact mechanism of action of these drugs and their potency is beyond the scopes of the present review, therefore we simply list the drugs that have been associated with positive outcomes of alcohol dependence.

In Italy and Austria, sodium oxybate is already approved for alcohol dependence and it is expected to will be soon introduced in Kazakhstan. Sodium oxybate is a short-chain fatty acid, structurally similar to the inhibitory neurotransmitter $\gamma$-amino-butyric acid, which exerts an ethanol-mimicking effect on GABAB receptors in the central nervous system. Baclofen is a GABAB receptor agonist currently used to control spasticity that was also shown to reduce alcohol consumption. Ondansetron is a 5-HT3 receptor antagonist that is thought to reduce the reward from alcohol. Additionally, other compounds clinically approved for different than alcohol addiction indications, such as pregabalin, oxcarbamazepine, gabapentin, valproic acid, aripiprazole, prazosin, vigabatrin, tiagabine, quetiapine and neurosteroids, seem to be able to reduce alcohol consumption, but further trials should be performed to confirm their efficacy in preventing relapse and maintaining complete abstinence [73-75].

\section{CONCLUSIONS AND FUTURE PERSPECTIVES}

It is anticipated that treating effectively alcohol dependence will decrease social and economic burden of this serious disorder. As it was extensively described in the present review, pharmacogenomics of alcohol dependence is a field in which several applications are mature and ready to be implemented in routine clinical practice. OPRM1 A118G polymorphism is highly associated with improved response to naltrexone. This gene polymorphism can serve a marker to distinguish individuals who will benefit the most from naltrexone or who could be administered an alternative drug, such as acamprosate. Additionally, even prior of FDA approval of topiramate for treating alcohol dependence, it has been consistently shown that topiramate response is affected by GRIK1 $r s 2832407 C>A$ polymorphism. As for the other drugs used for alcohol dependence, further studies are needed before any conclusions can be drawn on their utility in personalizing alcohol addiction therapy.

It is expected that in the coming years alcohol dependence pharmacogenomics may be instrumental in personalizing drug addic- 
tion therapy by guiding the choice of pharmacotherapy. It is hoped that incorporation of pharmacogenomics in routine clinical practice will lead to increased days of abstinence, lower relapse rates and days of heavy drinking, as well as lower incidence of drug adverse events. More importantly, application of pharmacogenomics in the field of alcohol dependence may lead to increased productivity of individuals who are currently addicted to alcohol. Overall, application of personalized medicine approaches on alcohol dependence therapy with the use of pharmacogenomics may provide with benefits all the players involved: the patients who may respond faster and more effectively to pharmacotherapy, the psychiatrists who - by integrating the latest and most updated scientific information in their practice - will increase therapy response rates, and the national health systems in each country as well as the society as a whole as it may help to reduce the financial and social burden of alcoholdependence.

\section{REFERENCES}

1.World Health Organization. Global Status report on Alcohol and Health. 2014.

2. Cargiulo T. Understanding the health impact of alcohol dependence. Am J Health Syst Pharm 2007;64:S5-11.

3. Kresina TF. Medication assisted treatment of drug abuse and dependence: global availability and utilization. Recent Pat Antiinfect Drug Discov 2007;2:79-86.

4. Assanangkornchai S, Srisurapanont M. The treatment of alcohol dependence. Curr Opin Psychiatry 2007;20:222-7.

5. Mann K, Hermann D. Individualised treatment in alcohol-dependent patients. Eur Arch Psychiatry Clin Neurosci 2010;260 Suppl 2:S116-20.

6. Edens E, Massa A, Petrakis I. Novel pharmacological approaches to drug abuse treatment. Curr Top Behav Neurosci 2010;3:343-86.

7. Soyka M, Rosner S. Emerging drugs to treat alcoholism. Expert Opin Emerg Drugs 2010;15:695-711.

8. Manolopoulos VG. Pharmacogenomics and adverse drug reactions in diagnostic and clinical practice. Clin Chem Lab Med 2007;45:801-14.

9. Squassina A, Manchia M, Manolopoulos VG, Artac M, Lappa-Manakou C, Karkabouna S, Mitropoulos K, Del Zompo M, Patrinos GP. Realities and expectations of pharmacogenomics and personalized medicine: impact of translating genetic knowledge into clinical practice. Pharmacogenomics 2010;11:1149-67.
10. Ragia G, Giannakopoulou E, Karaglani M, Karantza IM, Tavridou A, Manolopoulos VG. Frequency of CYP450 enzyme gene polymorphisms in the Greek population: review of the literature, original findings and clinical significance. Drug Metabol Drug Interact 2014. DOI: 10.1515/ dmdi-2014-0006.

11. Ragia G, Kolovou V, Tavridou A, Elens L, Tselepis AD, Elisaf M, Van Schaik RH, Kolovou G, Manolopoulos VG. Lack of association of the p450 oxidoreductase ${ }^{\star} 28$ single nucleotide polymorphism with the lipid-lowering effect of statins in hypercholesterolemic patients. Mol Diagn Ther 2014;18:323-31

12. Giannakopoulou E, Ragia G, Kolovou V, Tavridou A, Tselepis AD, Elisaf M, Kolovou G, Manolopoulos VG. No impact of SLCO1B1 521T>C, 388A $>$ G and 411G $>A$ polymorphisms on response to statin therapy in the Greek population. Mol Biol Rep 2014;41:4631-8.

13. Arvanitidis K, Ragia G, Iordanidou M, Kyriaki S, Xanthi A, Tavridou A, Manolopoulos VG. Genetic polymorphisms of drug-metabolizing enzymes CYP2D6, CYP2C9, CYP2C19 and CYP3A5 in the Greek population. Fundam Clin Pharmacol 2007;21:419-26.

14. Kolovou G, Ragia G, Kolovou V, Mihas C, Katsiki N, Vasiliadis I, Mavrogeni S, Vartela V, Tavridou A, Manolopoulos VG. Impact of CYP3A5 Gene Polymorphism on Efficacy of Simvastatin. Open Cardiovasc Med J 2014;8:12-7.

15. Ragia G, Petridis I, Tavridou A, Christakidis D, Manolopoulos VG. Presence of CYP2C $9^{*} 3$ allele increases risk for hypoglycemia in Type 2 diabetic patients treated with sulfonylureas. Pharmacogenomics 2009;10:1781-7.

16. Ragia G, Tavridou A, Elens L, Van Schaik RH, Manolopoulos VG. CYP2C9² allele increases risk for hypoglycemia in $\mathrm{POR}^{*} 1 /{ }^{*} 1$ type 2 diabetic patients treated with sulfonylureas. Exp Clin Endocrinol Diabetes 2014;122:60-3.

17. Ragia G, Arvanitidis KI, Tavridou A, Manolopoulos VG. Need for reassessment of reported CYP2C19 allele frequencies in various populations in view of CYP2C19*17 discovery: the case of Greece. Pharmacogenomics 2009;10:43-9.

18. Ragia G, Tavridou A, Petridis I, Manolopoulos VG. Association of KCNJ11 E23K gene polymorphism with hypoglycemia in sulfonylurea-treated type 2 diabetic patients. Diabetes Res Clin Pract 2012;98:119-24.

19. Iordanidou M, Paraskakis E, Tavridou A, Paschou P, Chatzimichael A, Manolopoulos VG. G894T polymorphism of eNOS gene is a predictor of response to combination of inhaled corticosteroids with long-lasting beta2-agonists in asthmatic children. Pharmacogenomics 2012;13:1363-72.

20. Manolopoulos VG, Dechairo B, Huriez A, Kühn A, Llerena A, van Schaik RH, Yeo KT, Ragia G, Siest G. Pharmacogenomics and personalized medicine in clinical practice. Pharmacogenomics 2011;12:597-610.

21. Manolopoulos VG, Ragia G, Alevizopoulos G. Pharmacokinetic interactions of selective serotonin reuptake inhibitors with other commonly prescribed drugs in the era of pharmacogenomics. Drug Metabol Drug Interact 
2011;27:19-31.

22. Manolopoulos VG, Ragia G, Tavridou A. Pharmacogenomics of oral antidiabetic medications: current data and pharmacoepigenomic perspective. Pharmacogenomics 2011;12:1161-91.

23. Manolopoulos VG, Ragia G, Tavridou A. Pharmacogenetics of coumarinic oral anticoagulants. Pharmacogenomics 2010;11:493-6.

24. Verhoef TI, Ragia G, de Boer A, Barallon R, Kolovou G, Kolovou V, Konstantinides S, Le Cessie S, Maltezos E, van der Meer FJ, Redekop WK, Remkes M,Rosendaal FR, van Schie RM, Tavridou A, Tziakas D, Wadelius M, Manolopoulos VG, Maitland-van der Zee AH; EU-PACT Group. A randomized trial of genotype-guided dosing of acenocoumarol and phenprocoumon. N Engl J Med 2013;369:2304-12.

25. Pirmohamed M1, Burnside G, Eriksson N, Jorgensen $\mathrm{AL}$, Toh $\mathrm{CH}$, Nicholson T, Kesteven P, Christersson C, Wahlström B, Stafberg C, Zhang JE, Leathart JB,Kohnke H, Maitland-van der Zee AH, Williamson PR, Daly AK, Avery P, Kamali F, Wadelius M; EU-PACT Group. A randomized trial of genotype-guided dosing of warfarin. $\mathrm{N}$ Engl J Med 2013;369:2294-303.

26. Kranzler HR, Edenberg HJ. Pharmacogenetics of alcohol and alcohol dependence treatment. Curr Pharm Des 2010;16:2141-8.

27. Ray LA, Chin PF, Miotto K. Naltrexone for the treatment of alcoholism: clinical findings, mechanisms of action, and pharmacogenetics. CNS Neurol Disord Drug Targets 2010;9:13-22.

28. Bond C1, LaForge KS, Tian M, Melia D, Zhang S, Borg L, Gong J, Schluger J, Strong JA, Leal SM, Tischfield JA, Kreek MJ, Yu L. Single-nucleotide polymorphism in the human mu opioid receptor gene alters beta-endorphin binding and activity: possible implications for opiate addiction. Proc Natl Acad Sci U S A 1998;95:9608-13.

29. Wand GS1, McCaul M, Yang X, Reynolds J, Gotjen $\mathrm{D}$, Lee S, Ali A. The mu-opioid receptor gene polymorphism (A118G) alters HPA axis activation induced by opioid receptor blockade. Neuropsychopharmacology 2002;26:106-14

30. Hernandez-Avila CA, Wand G, Luo X, Gelernter J, Kranzler HR. Association between the cortisol response to opioid blockade and the Asn40Asp polymorphism at the mu-opioid receptor locus (OPRM1). Am J Med Genet B Neuropsychiatr Genet 2003;118B:60-5.

31. Chong RY, Oswald L, Yang X, Uhart M, Lin PI, Wand GS. The mu-opioid receptor polymorphism A118G predicts cortisol responses to naloxone and stress. Neuropsychopharmacology 2006;31:204-11.

32. Ray LA, Hutchison KE, Ashenhurst JR, Morrow AL. Naltrexone selectively elevates GABAergic neuroactive steroid levels in heavy drinkers with the Asp40 allele of the OPRM1 gene: a pilot investigation. Alcohol Clin Exp Res 2010;34:1479-87.

33. Ray LA, Hutchison KE. A polymorphism of the mu-opioid receptor gene (OPRM1) and sensitivity to the effects of alcohol in humans. Alcohol Clin Exp Res 2004;28:1789-95.

34. Ray LA, Hutchison KE. Effects of naltrexone on alcohol sensitivity and genetic moderators of medication response: a double-blind placebo-controlled study. Arch Gen Psychiatry 2007;64:1069-77.

35. Oslin DW, Berrettini W, Kranzler HR, Pettinati H, Gelernter J, Volpicelli JR, O'Brien CP. A functional polymorphism of the mu-opioid receptor gene is associated with naltrexone response in alcohol-dependent patients. Neuropsychopharmacology. 2003 Aug;28(8):1546-52.

36. Anton RF, Oroszi G, O’Malley S, Couper D, Swift R, Pettinati H, Goldman D. An evaluation of mu-opioid receptor (OPRM1) as a predictor of naltrexone response in the treatment of alcohol dependence: results from the Combined Pharmacotherapies and Behavioral Interventions for Alcohol Dependence (COMBINE) study. Arch Gen Psychiatry 2008;65:135-44

37. Ooteman W, Naassila M, Koeter MW, Verheul R, Schippers GM, Houchi H, Daoust M, van den Brink W. Predicting the effect of naltrexone and acamprosate in alcohol-dependent patients using genetic indicators. Addict Biol 2009;14:328-37.

38. Oroszi G, Anton RF, O’Malley S, Swift R, Pettinati H, Couper D, Yuan Q, Goldman D.OPRM1 Asn40Asp predicts response to naltrexone treatment: a haplotype-based approach. Alcohol Clin Exp Res 2009;33:383-93.

39. Kim SG, Kim CM, Choi SW, Jae YM, Lee HG, Son BK, Kim JG, Choi YS, Kim HO, Kim SY, Oslin DW.A micro opioid receptor gene polymorphism (A118G) and naltrexone treatment response in adherent Korean alcohol-dependent patients. Psychopharmacology (Berl) 2009;201:611-8.

40. Setiawan E, Pihl RO, Cox SM, Gianoulakis C, Palmour RM, Benkelfat C, Leyton M.The effect of naltrexone on alcohol's stimulant properties and self-administration behavior in social drinkers: influence of gender and genotype. Alcohol Clin Exp Res 2011;35:1134-41.

41. Ray LA, Bujarski S, Chin PF, Miotto K. Pharmacogenetics of naltrexone in asian americans: a randomized placebo-controlled laboratory study. Neuropsychopharmacology 2012;37:445-55.

42. Chen AC, Morgenstern J, Davis CM, Kuerbis AN, Covault J, Kranzler HR. Variation in Mu-Opioid Receptor Gene as a Moderator of Naltrexone Treatment to Reduce Heavy Drinking in a High Functioning Cohort. J Alcohol Drug Depend 2013;1:101

43. McGeary JE, Monti PM, Rohsenow DJ, Tidey J, Swift R, Miranda R, Jr. Genetic moderators of naltrexone's effects on alcohol cue reactivity. Alcohol Clin Exp Res 2006;30:1288-96

44. Kranzler HR, Armeli S, Covault J, Tennen H. Variation in OPRM1 moderates the effect of desire to drink on subsequent drinking and its attenuation by naltrexone treatment. Addict Biol 2012;18:193-201.

45. Johnson JA, Klein TE, Relling MV. Clinical implementation of pharmacogenetics: more than one gene at a time. 
Clin Pharmacol Ther 2013;93:384-5.

46. Ashenhurst JR, Bujarski S, Ray LA. Delta and kappa opioid receptor polymorphisms influence the effects of naltrexone on subjective responses to alcohol. Pharmacol Biochem Behav 2012;103:253-9.

47. Anton RF, Voronin KK, Randall PK, Myrick H, Tiffany A. Naltrexone modification of drinking effects in a subacute treatment and bar-lab paradigm: influence of OPRM1 and dopamine transporter (SLC6A3) genes. Alcohol Clin Exp Res 2012;36:2000-7.

48. Schacht JP, Anton RF, Voronin KE, Randall PK, Li X, Henderson S, Myrick H.Interacting effects of naltrexone and OPRM1 and DAT1 variation on the neural response to alcohol cues. Neuropsychopharmacology 2012;38:41422.

49. Ray LA, Bujarski S, Squeglia LM, Ashenhurst JR, Anton RF. Interactive effects of OPRM1 and DAT1 genetic variation on subjective responses to alcohol. Alcohol Alcohol 2014;49:261-70.

50. Haidich AB. Meta-analysis in medical research. Hippokratia 2010;14:29-37.

51. Chamorro AJ, Marcos M, Miron-Canelo JA, Pastor I, Gonzalez-Sarmiento R, Laso FJ. Association of micro-opioid receptor (OPRM1) gene polymorphism with response to naltrexone in alcohol dependence: a systematic review and meta-analysis. Addict Biol 2012;17:505-12.

52. Gelernter J, Gueorguieva R, Kranzler HR, Zhang H, Cramer J, Rosenheck R, Krystal JH,VA Cooperative Study \#425 Study Group. Opioid receptor gene (OPRM1, OPRK1, and OPRD1) variants and response to naltrexone treatment for alcohol dependence: results from the VA Cooperative Study. Alcohol Clin Exp Res 2007;31:555-63.

53. Mitchell JM, Fields HL, White RL, Meadoff TM, Joslyn G, Rowbotham MC. The Asp40 mu-opioid receptor allele does not predict naltrexone treatment efficacy in heavy drinkers. J Clin Psychopharmacol 2007;27:112-5.

54. O’Malley SS, Robin RW, Levenson AL, GreyWolf I, Chance LE, Hodgkinson CA, Romano D, Robinson J, Meandzija B, Stillner V, Wu R, Goldman D.Naltrexone alone and with sertraline for the treatment of alcohol dependence in Alaska natives and non-natives residing in rural settings: a randomized controlled trial. Alcohol Clin Exp Res 2008;32:1271-83.

55. Tidey JW, Monti PM, Rohsenow DJ, Gwaltney CJ, Miranda R Jr, McGeary JE, MacKillop J, Swift RM, Abrams DB, Shiffman S, Paty JA.Moderators of naltrexone's effects on drinking, urge, and alcohol effects in non-treatmentseeking heavy drinkers in the natural environment. Alcohol Clin Exp Res 2008;32:58-66.

56. Coller JK, Cahill S, Edmonds C, Farquharson AL, Longo M, Minniti R, Sullivan T, Somogyi AA, White JM.OPRM1 A118G genotype fails to predict the effectiveness of naltrexone treatment for alcohol dependence. Pharmacogenet Genomics 2011;21:902-5.

57. Arias AJ, Armeli S, Gelernter J, Covault J, Kallio A, Karhuvaara S, Koivisto T, Mäkelä R, Kranzler HR.Effects of opioid receptor gene variation on targeted nalme- fene treatment in heavy drinkers. Alcohol Clin Exp Res 2008;32:1159-66

58. Spanagel R, Vengeliene V1, Jandeleit B2, Fischer WN2, Grindstaff K2, Zhang X2, Gallop MA2, Krstew EV3, Lawrence AJ3, Kiefer F4. Acamprosate produces its antirelapse effects via calcium. Neuropsychopharmacology 2013;39:783-91

59. Knudsen HK, Roman PM. Dissemination, adoption, and implementation of acamprosate for treating alcohol use disorders. J Stud Alcohol Drugs 2014;75:467-75.

60. Petersen EN. The pharmacology and toxicology of disulfiram and its metabolites. Acta Psychiatr Scand Suppl 1992;369:7-13.

61. Barth KS, Malcolm RJ. Disulfiram: an old therapeutic with new applications. CNS Neurol Disord Drug Targets 2010;9:5-12.

62. Cubells JF, Zabetian CP. Human genetics of plasma dopamine beta-hydroxylase activity: applications to research in psychiatry and neurology. Psychopharmacology (Berl) 2004;174:463-76.

63. Haile CN, Kosten TR, Kosten TA. Pharmacogenetic treatments for drug addiction: cocaine, amphetamine and methamphetamine. The American journal of drug and alcohol abuse 2009;35:161-77.

64. Mutschler J, Abbruzzese E, Witt SH, Dirican G, Nieratschker V, Frank J, Grosshans M, Rietschel M, Kiefer F. Functional polymorphism of the dopamine beta-hydroxylase gene is associated with increased risk of disulfiraminduced adverse effects in alcohol-dependent patients. J Clin Psychopharmacol 2012;32:578-80.

65. Florez G, Saiz PA, Garcia-Portilla P, Alvarez S, Nogueiras L, Bobes J. Topiramate for the treatment of alcohol dependence: comparison with naltrexone. Eur Addict Res 2011;17:29-36.

66. Paparrigopoulos T, Tzavellas E, Karaiskos D, Kourlaba G, Liappas I. Treatment of alcohol dependence with lowdose topiramate: an open-label controlled study. BMC Psychiatry 2011;11:41.

67. Olmsted CL, Kockler DR. Topiramate for alcohol dependence. Ann Pharmacother 2008;42:1475-80.

68. Rubio G, Martinez-Gras I, Manzanares J. Modulation of impulsivity by topiramate: implications for the treatment of alcohol dependence. Journal of clinical psychopharmacology 2009;29:584-9.

69. Ray LA, Miranda R Jr, MacKillop J, McGeary J, Tidey JW, Rohsenow DJ, Gwaltney C, Swift RW, Monti PM.A preliminary pharmacogenetic investigation of adverse events from topiramate in heavy drinkers. Exp Clin Psychopharmacol 2009;17:122-9.

70. Kranzler HR, Covault J, Feinn R, Armeli S, Tennen H, Arias AJ, Gelernter J, Pond T, Oncken C, Kampman KM. Topiramate treatment for heavy drinkers: moderation by a GRIK1 polymorphism. Am J Psychiatry 2014;171:445-52.

71. Kranzler HR, Feinn R, Gelernter J, Pond T, Covault J. Topiramate's Reduction of Body Mass Index in Heavy 
Drinkers: Lack of Moderation by a GRIK1 Polymorphism. Exp Clin Psychopharmacol 2014; DOI: 10.1037/ a0037309.

72. Kranzler HR, Armeli S, Feinn R, Tennen H, Gelernter J, Covault J. GRIK1 Genotype moderates topiramate's effects on daily drinking level, expectations of alcohol's positive effects and desire to drink. Int J Neuropsychopharmacol 2014;1-8.

73. Caputo F, Vignoli T, Grignaschi A, Cibin M, Addolorato G, Bernardi M. Pharmacological management of alcohol dependence: from mono-therapy to pharmacogenetics and beyond. Eur Neuropsychopharmacol 2014;24:181-91.

74. Howland RH. Baclofen for the treatment of alcohol dependence. J Psychosoc Nurs Ment Health Serv 2012;50:11-4.

75. Oulis P, Konstantakopoulos G. Efficacy and safety of pregabalin in the treatment of alcohol and benzodiazepine dependence. Expert Opin Investig Drugs 2012;21:101929. 


\title{
Farmakogenomika u alkoholizmu: personalizovani farmakološki tretman alkoholizma
}

\author{
Georgia Ragia $^{1,2}$, Vangelis G. Manolopoulos ${ }^{1,3}$ \\ ${ }^{1}$ Laboratory of Pharmacology, Medical School, Democritus University of Thrace, Alexandroupolis, Greece \\ ${ }^{2}$ DNALEX S.A., Leontaridou 2, Alexandroupolis, Greece \\ ${ }^{3}$ Clinical Pharmacology Unit, Academic General Hospital of Evros, Alexandroupolis, Greece
}

\section{KRATAK SADRŽAJ}

Zavisnost od alkohola je ozbiljan psihijatrijski poremećaj sa štetnim fizičkim, mentalnim i socijalnim posledicama, sa velikom verovatnoćom da ima hroničan tok. Mogućnosti farmakološkog tretmana zavisnosti od alkohola, kao i potrebe za pijenjem alkohola se rapidno proširuju.

Lekovi koji redukuju relapse kod alkoholičara kao i pijenje alkohola alkoholičara, dakle, lekovi koji se koriste za farmakološki tretman lečenja alkoholizma su: naltrekson, akamprosat i disulfiram, a topiramat je lek koji obećava kao efikasna terapija. Međutim, kod mnogih pacijente ova farmakoterapija nije efikasna. Rezultati iz brojnih različitih studija ukazuju da genetičke varijacije bitno doprinose interindividualnoj varijaciji kliničke prezentacije bolesti alkoholizam i terapijskog odgovora na primenjenu farmakoterapiju.

U ovom revijalnom radu sumiramo i razmotramo rezultate istraživanja o povezanosti genskog polimorfizma i terapijske odgovore na lekove protiv zavisnosti od alkohola. Pretpostavlja se da će buduća implementacija farmakogenomike u kliničku praksu pomoći da se personalizije lečenje od alkoholne zavisnosti, tj razvije personalizovana bolnička farmakologija.

Ključne reči: alkohol, zavisnost, naltrekson, topiramat, disulfiram, akamprosat, farmakogenetika, personalizovana bolnička farmakologija 